\title{
Analysis of Testing Methods for Chloride Ion Permeability in Marine Concrete
}

\author{
ZHANG Qingzhang ${ }^{1, a} \quad$ XI Da $a^{1, b}$ \\ ${ }^{1}$ College of Civil Engineering and Architecture, Henan University of Technology Zhengzhou \\ 450001, China; \\ azqz313@163.com, b928288681@qq.com
}

Keywords: marine concrete; chloride ion; permeability; testing method

Abstract. Chloride ion permeation is the most important factor for durability of concrete in marine environment. Therefore, it is the basic on durability design of concrete structures to choose reliable and accurate testing method for chloride ion permeability in concrete. In this paper, according to transport process reflect practical or impractical migration of chloride ion in concrete, testing methods were classified. The principle and application range of each method were analyzed, and the existing problems for each method are discussed. In order to adopted test methods for chloride ion permeating in concrete are scientific and accurate.

\section{Introduction}

In recent years, the problem of the durability of the concrete has become the most fashionable spots in the research field of the concrete, especially in the concrete structure under the marine environment. The chloride ions penetrated into the internal concrete damage of reinforced passivation membrane of rebar surface, and it causes the steel corrosion and reduces the service life of the structure. Recently, the marine engineering concrete structure under the chloride salt erosion damage has become a universal problem concerned in world[1][2]. The relationship between the permeability of the chloride and the durability of the marine concrete structures is very relevant. So concrete chloride ion permeability test methods are widely used in the durability of concrete structure design, construction design, the prediction of the quality of concrete structure durability life, etc. To measure the permeability of chloride ion in concrete, scholars of every country perform some researches, and put forward lots of testing methods. But different methods have their own limitations, different testing methods for chloride ion permeability in concrete is different. Inconsistent standard disunion will cause difficulty in widely application[3][4].

This article, it was analyzed to the testing principle of the chloride ion accelerated testing method, the applicable scope and whether to reflect the actual transmission of the chloride ions, in order to the appropriate testing methods in the study of accelerating research for chloride ion were adopted.

\section{The simulate method reflecting chloride ion actual migrating process}

In order to reflect the objectively real transmission process of chloride ion in concrete, lots of testing method for reflecting chloride ion actual migrating process are adopted to evaluate penetration performance of chloride ion into concrete, such as diffusion slot accelerated testing method, long-term immersion method with salt solution and accelerated simulation method, etc.

Diffusion cell method. Diffusion cell method is a method, which is one of the direct method for determinating of chloride ion diffusion coefficient. The method accords with the actual transmission process of chloride ions in concrete, the precision is relatively easy to be controlled, and it has been widely applied. Diffusion method is a method to place concrete thin specimen between two of the same size solution pool, pour solution into two different solution pools, $\mathrm{NaCl}$ solution in upstream room and $\mathrm{Ca}(\mathrm{OH})_{2}$ solution in downstream room. After a period of time, waiting for the stable condition with chloride ion diffusion, the concentration of chloride ion was measured in the pool which is poured into 
$\mathrm{Ca}(\mathrm{OH})_{2}[5]$. According to Fick's first law, the chloride ion diffusion coefficient can be calculated by the formula (1):

$$
D=b \frac{V L}{C_{0} A}
$$

Where, $D$ is the chloride ion diffusion coefficient $\left(\mathrm{m}^{2} / \mathrm{s}\right) ; b$ is the rate of change of chloride ion concentration in downstream room after reaching stable $(\%) ; \mathrm{V}$-volume of the downstream room solution $\left(\mathrm{m}^{3}\right) ; L$ is the thickness of the specimen $(\mathrm{m}) ; C_{0}$ is chloride ion initial concentration in upstream room $(\%) ; A$ is the contact area between the specimen and the solution $\left(\mathrm{m}^{2}\right)$.

This method need consume time, it is widely used in mortar and net pulp specimen, but less in the experiment of concrete.

Long-term immersion method with salt solution. Generally, scholars studied the chloride ion diffusion in concrete by solution in America until 1981. Long-term immersion method with salt AASHTO T259 is the earliest chloride ion diffusion test standard method in America[6]. Then, the method was improved by European, and the testing standard Nord Test and NT Build443-94 have been implemented on the basis of the American.

AASHTO T259 need to make a closed-around concrete specimen, bottom of which is $300 \times 300 \mathrm{~mm}$, and the thickness is more than $75 \mathrm{~mm}$, and were exposed with the up and down opposite face. The specimen were soaked in the water for 14 days, and conserved the 28 days under the $50 \%$ relative humidity environment. The $3 \% \mathrm{NaCl}$ solution were put into the specimen's top for a period of time, which is approximate 35 days for ordinary concrete or 90 days or longer for high strength and high performance concrete. The concrete specimen's chloride ion concentration was ascertained in different depth of specimen by grinding or drilling from the surface of the concrete specimen, then subtract the initial chloride ion concentration. Finally, the curve between chloride ion concentration and depth was obtain, and the diffusion coefficient were ascertained by regression according to Fick's second law. Test apparatus is shown in Fig. 1.

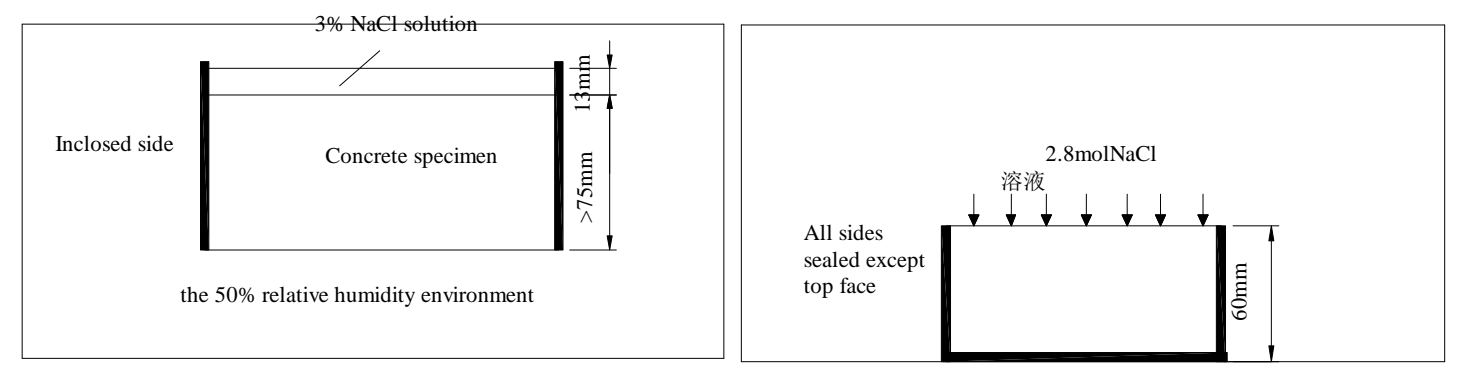

Figure 1 Testing apparatus AASHTO T259 Figure 2 Testing apparatus NT Build 443-94

The about $60 \mathrm{~mm}$ concrete specimens were immersed the concentration of $2.8 \mathrm{~mol} / \mathrm{L} \mathrm{NaCl}$ solution by Nord Test NT build443-94, which have one exposed surface. Ordinary concrete need to be soaked 35 days, high strength or high performance concrete need to be soaked 90 days or longer. The curve between chloride ion concentration and depth was obtain, and the diffusion coefficient were ascertained by regression according to Fick's second law. Test apparatus is shown in Fig. 2.

Long-term immersion method with salt solution is a usual way to determine the chloride ion diffusion coefficient in concrete, and it is very close to the actual situation. However, this kind of method need much long time, which takes a few weeks or even several months. For high strength or high performance concrete, which need more time to test. In addition, the test process is complicated, which should be developed to a powder, leaching, electrochemical titration, mathematical fitting and any other steps, and surface chloride ion concentration can't been knowed. So there are major error for test result. Especially when the chloride ion infiltration depth is small, the early concrete chloride ion diffusion coefficient can't been ascertained due to less number of available slices.

Accelerated testing simulation method. Concrete natural exposure test under the marine environment can reflect the real case of chloride ion permeation. But due to the long test period and the poor reproducibility, the current test data is not used to reveal the chloride ion permeation mechanism and predict concrete structure durability life. To marine atmospheric zone, splash zone, tidal zone and 
underwater zone any other different partitions, scholars designed different accelerated testing simulation method respectively, according to the salinity, temperature, relative humidity, wetting-drying cycle and ratio to chloride ion permeation rule. K. Hong completed the tests to study of chloride ion permeability in concrete, which include two kinds of wetting-drying circulate system. The specimens were immersed in the salt solution for $6 \mathrm{~h}$, then respectively were placed the box with maintain constant temperature and humidity for $18 \mathrm{~h}$ and $66 \mathrm{~h}$. A. Konin place a wetting-drying cycling test for once every two weeks, which spent one year. In addition, Y.S. Yuan, T.C. Wang, Y. ZHANG, H.Y XIAO and any other Chinese scholars has carried on the accelerated testing with different sample parameter. Values of these parameters as shown in Table 1[7-13].

Table 1 Accelerated test parameters at home and abroad

\begin{tabular}{|c|c|c|c|c|c|}
\hline Author & Specimen size & $\begin{array}{l}\text { Chloride ion } \\
\text { concentration }\end{array}$ & $\begin{array}{l}\text { Curing } \\
\text { temperature }\end{array}$ & $\begin{array}{l}\text { Relative } \\
\text { humidity }\end{array}$ & Wetting-drying way \\
\hline K.Hong & $\begin{array}{l}\text { Thickness } 50 \mathrm{~mm} \text {, diameter } \\
\text { 100mm cylinder }\end{array}$ & $1.0 \mathrm{molNaCl}$ & $23^{\circ} \mathrm{C}$ & $50 \%$ & $\begin{array}{l}\text { Soaking } 6 \mathrm{~h}, \text { dryign } 18 \mathrm{~h}: \\
\text { Soaking } 6 \mathrm{~h} \text { drying } 66 \mathrm{~h} .\end{array}$ \\
\hline A.Konin & $100 \mathrm{~mm}, 100 \mathrm{~mm}, 500 \mathrm{~mm}$ & $35 \mathrm{~g} / \mathrm{L} \mathrm{NaCl}$ & $\begin{array}{l}\text { Without } \\
\text { considering }\end{array}$ & $\begin{array}{l}\text { Without } \\
\text { considering }\end{array}$ & $\begin{array}{l}\text { Every two weeks, wetting-drying } \\
\text { circulation. }\end{array}$ \\
\hline G. Xu & $100 \mathrm{~mm}, 100 \mathrm{~mm}, 400 \mathrm{~mm}$ & $7 \% \mathrm{NaCl}$ & $\begin{array}{l}\text { Without } \\
\text { considering }\end{array}$ & $\begin{array}{l}\text { Without } \\
\text { considering }\end{array}$ & Wetting-drying ratio $0.2 \sim 5$ : \\
\hline Y.S YUAN & $100 \mathrm{~mm}, 150 \mathrm{~mm}, 300 \mathrm{~mm}$ & $15 \% \mathrm{NaCl}$ & $\begin{array}{l}10^{\circ} \mathrm{C}, 22^{\circ} \mathrm{C} \\
, 35^{\circ} \mathrm{C}\end{array}$ & $70 \%, 80 \%, 90 \%$ & Atmospheric environment and soaking. \\
\hline T.C. Wang & $40 \mathrm{~mm}, 40 \mathrm{~mm}, 160 \mathrm{~mm}$ & $\begin{array}{l}5 \text { times as much } \\
\text { as the sea water }\end{array}$ & $80^{\circ} \mathrm{C}$ & $\begin{array}{l}\text { Without } \\
\text { considering }\end{array}$ & soaking $8 \mathrm{~h}$, drying $16 \mathrm{~h}$ : \\
\hline Y. ZHANG & $150 \mathrm{~mm}, 150 \mathrm{~mm}, 550 \mathrm{~mm}$ & $5.76 \% \mathrm{NaCl}$ & $46^{\circ} \mathrm{C}$ & $80 \%$ & $\begin{array}{l}\text { soaking } 6 \mathrm{~h} \text {, drying } 42 \mathrm{~h}: \\
\text { soaking } 4 \mathrm{~h} \text {, drying } 68 \mathrm{~h}:\end{array}$ \\
\hline H.Y XIAO & $40 \mathrm{~mm}, 40 \mathrm{~mm}, 160 \mathrm{~mm}$ & $\mathrm{Cl}^{-}: 50 \mathrm{~g} / \mathrm{L}$ & $70^{\circ} \mathrm{C}$ & $\begin{array}{l}\text { Without } \\
\text { considering }\end{array}$ & soaking $8 \mathrm{~h}$, drying $16 \mathrm{~h}$ : \\
\hline
\end{tabular}

For accelerated testing simulation method, environment parameters are very important. Salt solution concentration is an important parameter of the accelerated simulation. Too high or too low of the salt solution concentration could will cause the differences of accelerated simulation. When the salt solution concentration is too large, it may cause saturation of pore solution with the chloride ions in concrete, and outside chloride ions is hard to penetrate into concrete. So the test results can't reflect the intrusion situation of chloride ions in this salt solution concentration.

From Table 1, it can be found that the salt solution concentration usually be controlled at 5\% to $15 \%$, and a small amount of standards adopt the salt solution concentration about $3 \%$.

Temperature has important effect on chloride ion intrusion speed. Now, temperature range of the accelerated testing is between $20^{\circ} \mathrm{C} \sim 80^{\circ} \mathrm{C}$. The temperature and humidity influences each other, and external humidity is in commonly between $50 \% \sim 80 \%$.

There are some ways about chloride ion penetration, like salt fog, soaking in sodium chloride solution and wetting-drying circulation. The wetting-drying ratio is also variational for the different parts of the actual structure under wetting-drying alternate environment. And according to the current research results, specific wetting-drying ratio value can't be ascertained to the biggest influence on the invasion of the chloride ion. From Table 1, it was found that wetting-drying cycle and dry wet ratio range is very large. There are no standard about the wetting-drying cycle and the choice of wetting-drying proportion.

Pressure permeation method. Pressure permeation method is different from the method which applied electric field to accelerate the transportation of chloride ion in concrete. This method apply the force on chloride ion solution to accelerated chloride ion permeability rate[14]. The method is described as follow: concrete specimens were saturated with water in advance preciously, and then put it into a completely closed place to avoid leakage. The solution with chloride ion was into injected apparatus, and then pressure was imposed. When pressure sustain to the set time, concretes were removed and the depth and content of chloride ion permeability was determined. Pressure can make chloride ion to permeate into concrete by pressure and diffusion, which can actually reflect the actual transport process of chloride ion in concrete. The higher requirement is needed because of the $\mathrm{NaCl}$ solution is easy to lake under the large loads and pressure. Now, there is little test data bout the pressure permeation test compared with other test methods. 


\section{The simulate method no reflecting chloride ion actual migrating process}

The test which reflect chloride ion migration process is tedious, and need for a long time, so scholars are looking for an accelerated testing methods that can determine concrete chloride ion permeability quickly and conveniently. Now, the common quick test methods include the American standard power method(ASTM C1202), modified CSIRO, RCM method, NEL method, etc.

ASTM C1202 method. Power method is short for American standard ASTM C1202, which was invented by Whiting in 1981. It is based on the diffusion cell method, and use extra electric field to speed up both ends of specimen solution ion transportation. The detailed test methods is: cut the concrete specimen into $50 \mathrm{~mm}$ thick and $100 \mathrm{~mm}$ diameter after $28 \mathrm{~d}$ curing. After water retention under vacuum condition, specimen was placed in the middle of the sink with $3.0 \% \mathrm{NaCl}$ solution and $0.3 \mathrm{~mol} / \mathrm{L} \mathrm{NaOH}$ solution in both ends. The specimen was put under the $60 \mathrm{~V}$ direct current for $6 \mathrm{~h}$, then the power of the whole process was recorded. Testing apparatus is shown in Fig. 3.

ASTM C1202 according to the flow of electricity within the stipulated time reflect the concrete ability about resistance chloride ion permeability. Evaluation criteria are shown in Table 2[15].

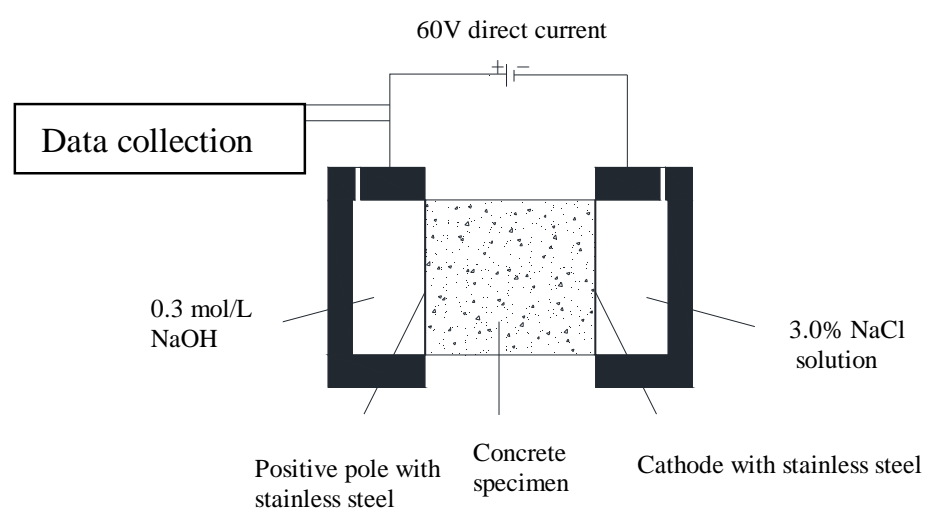

Figure 3 ASTM C 1202 testing apparatus

ASTM C1202 intuitively reflect the permeability of chloride ion in concrete, which is generally accepted test method for ascertaining the chloride ion permeability in common concrete. But this method also exists some shortage. (1) High voltage is easy to lead the electrode reaction and make the solution temperature high, which distract the test data.(2) When the test work have been finished, chloride ion diffusion has not reach the steady state.(3) The electric flow is related to solution of all ions including the chloride ion. In the process of electricity, the electric current is constantly changing, so the specimen was great influenced by electric current and record once every 30 minutes, which will cause big error. (5) The results can not be quantitatively illustrate the permeability of chlorine ion in concrete, especially which can't correctly reflect chloride ion permeability of concrete which was mixed fly ash, silicon ash and other admixtures.

Table 2 ASTM C 1202 chloride ion permeability evaluation standard

\begin{tabular}{ccc}
\hline Total amont of elecrticity in $6 \mathrm{~h}(\mathrm{C})$ & $\begin{array}{c}\text { Chloride ion } \\
\text { permeability }\end{array}$ & Typical concrete \\
\hline$>4000$ & High & Ordinary concrete $(\mathrm{W} / \mathrm{C} \geqslant 0.6)$ \\
$2000 \sim 4000$ & Middle & Ordinary concrete $(\mathrm{W} / \mathrm{C}=0.4 \sim 0.6)$ \\
$1000 \sim 2000$ & Low & Ordinary concrete $(\mathrm{W} / \mathrm{C}=0.3 \sim 0.4))$ \\
$100 \sim 1000$ & Too low & Latex improved, \\
$<100$ & Neglect & Silica fume concrete \\
\end{tabular}

Improvement CSIRO method. Improvement CSIRO method is put forward by the Australian CSIRO to improve the method of ASTM C1202. The preparation and test method of this method are according to ASTM C1202. The difference between improvement CSIRO method and ASTM C1202 method is as follows: for a number of specimens were tested twice, which are same batch and cured conditions obtained from the same cylinder block. One group is according to ASTM C1202 method, and the total consumption powers(TCPs) were used as the evaluation indexes. Another group use curing water to do the additional test, the total consumption powers(TCPw) was got as the evaluation 
indexes. Use TCPs-TCPw was used as final evaluation index in the method replacing ASTM C1202 method's TCPs. The method introduce TCPw values, and the influence of TCPs value to concrete pore solution composition and ion concentration's was considered. More accurate evaluation to the concrete chloride ion permeability can be got.

But this method also can't overcome some defects, such as voltage makes the solution temperature rise, ion diffusion have not reach a steady state, measured value is the result of the whole ion movement, etc. The evaluation criteria of this method as shown in Table 3[16].

Table 3 Concrete chloride ion permeability evaluation criteria in improvement CSIRO method

\begin{tabular}{cc}
\hline Total electricity & Chloride ion \\
$(\mathrm{C})$ & permeability \\
\hline$>3000$ & High \\
$2000 \sim 3000$ & Middle \\
$1000 \sim 2000$ & Low \\
$500 \sim 1000$ & Too low \\
$<500$ & Too low \\
\hline
\end{tabular}

RCM method. CTH was first put forward by professor L.P. Tang, became the Nordic standard Nord test NT Build492 later. Germany's RWTH Aachen university institute of building materials put forward CTH based on RCM method(Rapid Chloride Migration Test). Structure design and construction guide for durability of concrete was formulated by China Civil Engineering Society, also adopts RCM method. This method can calculate the chloride ion diffusion coefficient directly according to the depth of chloride ions into the concrete measurements, and quantitatively evaluate the concrete resistance to chloride ion diffusion ability. In principle, RCM method is similar with natural water diffusion method, ion transfer not only was driven by the concentration gradient, but also the potential gradient under external electric field. In the generally, potential gradient is the main driving force. The test equipment is shown in Fig. 4[17].

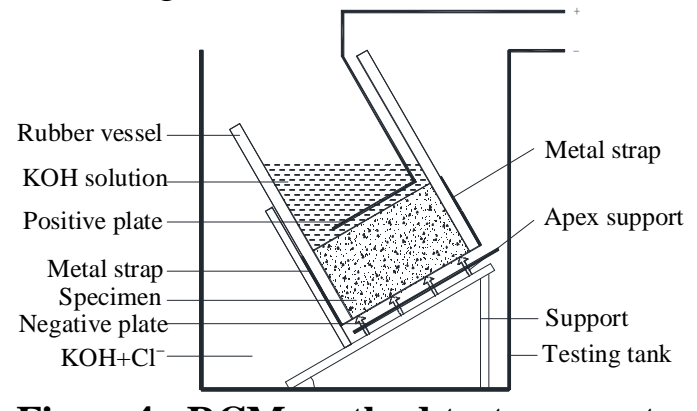

Figure4 RCM method test apparatus

The main steps of experiment: putting the specimen into standard size for $\phi 100 \mathrm{~mm}$ diameter, height $\mathrm{h}=50 \mathrm{~mm}$ cylinder specimens, and maintaining in the standard curing room pool to a certain age then the specimen to kept ultrasonic bath $120+20 \mathrm{~s}$. $0.2 \mathrm{~L} / \mathrm{mol} \mathrm{KOH}$ solution about $300 \mathrm{ml}$ was inject into the rubber cylinder. The sleeve immersed solution was put into the test cell which contains 5\% $\mathrm{NaCI}$ and $0.2 \mathrm{~mol} / \mathrm{L} \mathrm{KOH}$ solution, and the liquid level inside the sleeve should flush with the fluid level of the external test cell. Switching on $30 \mathrm{~V}$ direct current supply and recording time, and synchronously the voltage in parallel, series current and the electrolyte temperature were measure. Test to the set time, color indicator was sprayed on the surface of cleft specimen (fluorescent yellow solution), then 0.1 $\mathrm{mol} / \mathrm{L} \mathrm{AgNO} 3$ solution was sprayed when the surface has been dry. The depth of chloride ion diffusion can be measured. the average of each point were calculated, that is the depth of diffusion. The concrete chloride ion diffusion coefficient can be calculated by the formula(2) and (3).

$$
\begin{gathered}
D=2.872 \times 10^{-6} \frac{T h\left(x_{\mathrm{d}}\right)-a \sqrt{x_{d}}}{t} \\
a=3.338 \times 10^{-3} \sqrt{T h}
\end{gathered}
$$

Where, $D$ is the chloride ion diffusion coefficient by RCM method; $T$ is the average value of the initial and final temperature of anolyte $(\mathrm{K}) ; \mathrm{h}$ is the height of the specimen $(\mathrm{m}) ; x_{\mathrm{d}}$ - the depth of chloride ion diffusion $(\mathrm{m}) ; t$ is the galvanical test time (s). 
RCM method is simple, practical, and can simultaneously test multiple sets of test blocks. The chloride ion diffusion coefficient was quantitatively measured, and RCM method can make the phenomenon of the depth of chloride ion erosion is intuitive and clear. The test cycle also can be reduced. The existed experimental results have proved that correlation of RCM method with salt solution long-term immersion method and accelerated testing method is very good. Diffusion coefficient of chloride ion was determined, which is amended by referenced time parameters, environmental parameters and different gelling material parameters, then Fick's second law can be used to predict durability life of concrete structure. But RCM method did not fundamentally solve the problems existing in the experiment of power method, it also can not eliminate the electrode polarization problem. In the existing calculation model, the electroosmosis effect on the test results have not been considered.

NEL method. NEL method based on ion diffusion and electromigration is actually a full salt direct current conductivity method. The process of making concrete specimens full of salt was accelerated by vacuum suction method. Because the charged ions diffusion coefficient in concrete is relative to its electrical conductivity, the Nernst-Einstein equation was used to determine the chloride diffusion coefficient of concrete[18][19]. The test method is as follows: making specimens whose upper surface and lower surface are flat and the size is $100 \mathrm{~mm} \times 100 \mathrm{~mm} \times 50 \mathrm{~mm}$ or $\phi 100 \mathrm{~mm} \times 50 \mathrm{~mm}$, taking three specimens using $4 \mathrm{~mol} / \mathrm{L}$ vacuum full of salt solution to make them full of salt, putting specimens wiped the salt water on the surface between the two $\$ 50 \mathrm{~mm}$ copper electrodes of the holders, and the diffusion coefficient of full salt concrete specimens were ascertain to used NEL chloride ion diffusion coefficient testing device with smaller voltage $(1 \sim 10 \mathrm{~V})$. The test is completed within 15mins in generally, and the testing device is shown in Fig. 5.

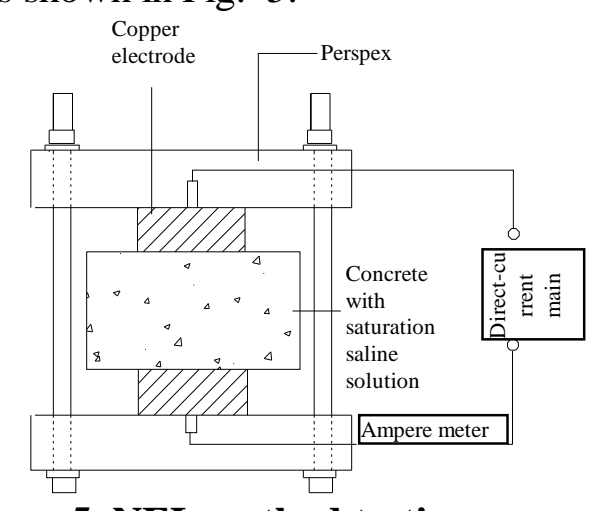

Figure5 NEL method testing apparatus

Table4 Evaluation criteria of concrete chloride ion permeability by NEL method

\begin{tabular}{cc}
$\begin{array}{c}\text { Chloride ion diffusion coefficient } \\
\left(\times 10^{-14} \mathrm{~m}^{2} / \mathrm{s}\right)\end{array}$ & $\begin{array}{c}\text { Evaluation of chloride ion } \\
\text { permeability }\end{array}$ \\
$>1000$ & Too high \\
$500 \sim 1000$ & High \\
100 & $\sim 500$ \\
$50 \sim 100$ & Middle \\
$10 \sim 50$ & Low \\
$<10$ & Too low \\
\hline
\end{tabular}

NEL method is responsive to water cement ratio and change of admixture, which is suitable for to evaluate various kinds performance permeability of concrete. It reduces the adverse impact of the electrode reaction by using smaller voltage. The problem was cleverly solved, which is difficult to determine the ion migration coefficient in Nernst-Einstein equation. However, this method directly measures specimens which are soaked in high concentrations of $\mathrm{NaCl}$ solution, which doesn't meet the assumptions and applicable conditions of Nernst-Einstein equation. Moreover, the chloride ion diffusion coefficient getting from NEL method is free chloride ion diffusion coefficient. Now, the study of combination between free chloride ion of concrete and free chloride ion concentration is not very 
thorough, so diffusion coefficient getting by NEL method cannot be directly used to predict concrete durability life by using Fick's second low. It normally was used to do rapid qualitative evaluation to concrete chloride ion permeability. The evaluation criteria of concrete chloride ion permeability of NEL method is shown in Table 4[20].

Above all kinds of concrete resistance to chloride ion permeability test method has its own respective scope of application and imitation, combine the above methods, as shown in Table 5.

Table5 Comparison of concrete chloride ion permeability test method

\begin{tabular}{|c|c|c|c|}
\hline Test method & $\begin{array}{l}\text { Whether or not under the } \\
\text { environment of constant } \\
\text { temperature }\end{array}$ & Test cycle & Scope of application \\
\hline $\begin{array}{l}\text { Diffusion cell } \\
\text { method }\end{array}$ & Yes & After a long time curing & $\begin{array}{l}\text { Design mix proportion, predict } \\
\text { durability life }\end{array}$ \\
\hline AASHTO T259 & Yes & $35 \sim 90 \mathrm{~d}$ or longer & $\begin{array}{l}\text { Design mix proportion, predict } \\
\text { durability life }\end{array}$ \\
\hline NT Build443-94 & Yes & $35 \sim 90 \mathrm{~d}$ or longer & $\begin{array}{l}\text { Design mix proportion, predict } \\
\text { durability life }\end{array}$ \\
\hline $\begin{array}{l}\text { Accelerated testing } \\
\text { simulation method }\end{array}$ & Yes & After a long time curing & $\begin{array}{l}\text { Design mix proportion, predict } \\
\text { durability life }\end{array}$ \\
\hline ASTM C1202 & No & After saturation $6 \mathrm{~h}$ & $\begin{array}{l}\text { Evaluate chloride ion } \\
\text { permeability }\end{array}$ \\
\hline $\begin{array}{l}\text { Pressure permeation } \\
\text { method }\end{array}$ & No & $\begin{array}{l}\text { Depend on pressure and } \\
\text { concrete performance }\end{array}$ & Roughly predict durability life \\
\hline RCM method & Yes & $4 \sim 168 \mathrm{~h}$ & $\begin{array}{l}\text { Evaluate chloride ion } \\
\text { permeability, roughly predict } \\
\text { durability life }\end{array}$ \\
\hline NEL method & Yes & $\begin{array}{l}\text { After saturated salt, } \\
\text { within } 15 \mathrm{~min}\end{array}$ & $\begin{array}{l}\text { Evaluate chloride ion } \\
\text { permeability }\end{array}$ \\
\hline
\end{tabular}

\section{Conclusions}

(1)The above analysis and summary descriptions of the testing methods on chloride ions permeability in concrete show that the test methods been improving, which provide experimental foundations for further researching on permeability of chloride ion in marine concrete.

(2)There are various ways to research permeability of chloride ion in concrete, but the principles and scopes are different. Diffusion cell method, AASHTO T259, NT Build443-94, Accelerated testing simulation method can be used for mixture ratio design and life prediction. Pressure permeation method, the RCM method and NEL method can only be used for the evaluation of the permeability of concrete in Generally. So choosing the proper test methods based on the research objective is very important.

(3)The evaluation standards of the testing methods are different, which leads to the differences in the test results by different methods. The relationships of various methods should be established to guide the applications in practical engineering.

\section{Acknowledgements}

This study is financially supported by National Natural Science Foundation of China (Grant No. 51509084), High-level Personnel Fund Program of Henan University of technology (Grant No. 2013BS026), and General Science and Technology Research Program of Zhengzhou (Grant No. 20140766).

\section{References}

[1]Z.Y. Chen: The Durability and Safety of Reinforced Concrete Structure and Crack Controlled (China Architecture and Building Press, 2013, in Chinese).

[2]T. Yang, B. W. Guan, X. K. Yang, et al: Concrete (2015, in Chinese). 
[3]C.C. Yang, S.W. Cho: submitted to Materials and Structures (2004).

[4]Y.S. JI: Performance and prediction of reinforced concrete in full service life due to corrosion damage (China Railway Publishing House, 2011, in Chinese).

[5]N.R. Buenfeld, J.Z. Zhang: submitted to Cement and Concrete Research (1999).

[6]K.D. Stanish, Rd. Hooton and Mda Thomas: Testing the chloride penetration resistance of concrete: a literature review. FHWA Contract DTFH61-97-R-00022. University of Toronto, Toronto, Ontario, Canada (2000).

[7]K. Hong, R.D. Hooton: submitted to Cement and Concrete Research (1999).

[8]A. Konin, R. Francois and G. Arliguie: submitted to Material and Structures (1998).

[9]G. Xu, K. Xu, Y.B. Su, et al: submitted to Journal of Building Materials (2014, in Chinese).

[10]C.F Lu, Y.S Yuan, H.X. Ji, et al: submitted to Journal of Zhejiang University (2012, in Chinese).

[11]Y.M. Zhang, T. C. Wang: submitted to Concrete (2001, in Chinese).

[12]Y. Zhang. Mechanics of chloride ions transportion in concrete. Zhejiang University (2008, in Chinese).

[13]H.Y. Xiao,Y. Ge, B.S. Zhang, et al: Study on corrosion characteristic of concrete under soaking way. The concrete durability of the sixth national academic communication (2004, in Chinese).

[14]F.G. Leng, G.F. Tian: submitted to Journal of Southeast University (Natural Science Edition) (2006, in Chinese).

[15]X.D. Wang, P. Zhang, T.J Zhao: submitted to Engineering design and construction (2004, in Chinese).

[16]C.Y. Gao, Y. Yao, L. Wang, et al: Research of test method for concrete resistance to chloride ion permeability. The fifth session of the national academic exchange on high performance concrete (2004, in Chinese).

[17]China Civil Engineering Society. Structure design and construction guide for durability of concrete (China Building Industry Press, 2005, in Chinese).

[18]X. Lu: submitted to Cement and Concrete Research (1997).

[19]B.G. Lu, H.Y. Qin: submitted to Concrete (2014, in Chinese).

[20]T.J. Zhao: Permeability of concrete (Science Press, 2006, in Chinese). 